\title{
Interaction of calcium and lead in human erythrocytes
}

\author{
C N ONG* AND W R LEE
}

From the Department of Occupational Health, University of Manchester, Manchester M13 9PT, UK

ABSTRACT The interactions of calcium and lead on the human erythrocytes have been studied in vitro using ${ }^{45} \mathrm{Ca}$ and ${ }^{203} \mathrm{~Pb}$ as tracers. The chemical groups binding calcium and lead on the erythrocytes were also investigated. Calcium ions in the plasma were shown to be capable of replacing the ${ }^{203} \mathrm{~Pb}$ on the red cells. More than $85 \%$ of the ${ }^{203} \mathrm{~Pb}$ in the erythrocyte was associated with the cytoplasmic components, and the rest was bound to the stromal membrane. About $90 \%$ of ${ }^{45} \mathrm{Ca}$ was attached to erythrocyte membrane. Extraction of ${ }^{45} \mathrm{Ca}$ and ${ }^{203} \mathrm{~Pb}$-labelled erythrocyte membranes with chloroform/methanol mixture showed that the distribution patterns of these two nuclides are similar, with over $88 \%$ protein bound, less than $10 \%$ lipid bound, and traces in the aqueous phase. Chemical modification of erythrocyte membrane proteins with carbodi-imide, p-chloromercuribenzoate (PCMB), and maleic anhydride suggested that the carboxyl groups are responsible for binding lead and calcium to the red cell membrane. The SH groups may have a minor role in the binding for both cations. Amino groups did not appear to affect the binding of these cations. Gel chromatography of ${ }^{45} \mathrm{Ca}$-labelled erythrocyte membrane indicated that $\mathrm{Ca}^{++}$bound to the same fraction of membrane proteins as ${ }^{203} \mathrm{~Pb}$, corresponding to a molecular weight of about 130000 to 230000 . A possible implication of these findings is that lead and calcium may compete for the same binding site(s) on the erythrocyte.

The exact mechanism by which calcium influences the metabolism of lead is not known. Several experiments, however, indicate that lead may affect the physiological functions of calcium.

Goyer and Rhyne ${ }^{1}$ suggested that the absorption of lead and the partitioning of lead in various body compartments are regulated by the same mechanism that controls the metabolism of calcium. Using experimental animals, Meredith $e^{2} a^{2}$ showed that doubling of dietary calcium caused a significant depression of oral lead absorption. Sorell et $a l^{3}$ showed that children with blood lead greater than $60 \mu \mathrm{g} / 100 \mathrm{ml}(3 \mu \mathrm{mol} / \mathrm{l})$ had a lower mean daily uptake of calcium and vitamin $D$ than those with a normal range of blood lead. It has also been shown in bone tissue cultures that an increase in $\mathrm{Ca}^{++}$ concentration in the culture medium decreases the efflux of lead from bone cells. 4

Kostial and Vouk ${ }^{5}$ observed that lead blocked the transmission of nerve impulses in the perfused

*Present address: Department of Social Medicine and Public Health, University of Singapore, Outram Hill, Singapore 3.

Received 11 December 1978

Accepted 18 May 1979 cervical ganglion. A similar phenomenon was also observed in frog sympathetic ganglia by Kober and Copper, ${ }^{6}$ who postulated that lead competes with the calcium in the presynaptic nerve terminals. In-vitro experiments have suggested that $\mathrm{PbCl}_{2}$ also exerts an effect on the neuromuscular junction.?

The present investigations were undertaken to evaluate the relation between lead and calcium in human erythrocytes. Attempts were also made to identify the calcium and lead binding sites in the erythrocytes.

\section{Materials}

Molecular weight markers for gel filtration were purchased from BDH Chemicals Ltd. Sephadex G-200 was purchased from Pharmacia (UK) Ltd.

${ }^{45} \mathrm{Ca}$ was a gift from the Radiation Protection Service, University of Manchester. The isotope is a $\beta$-emitter with a half-life of 165 days. ${ }^{203} \mathrm{~Pb}$ is prepared in the cyclotron by bombardment of a thallium target and is obtained carrier free. It was supplied by the Medical Research Council Cyclotron Unit, Hammersmith Hospital. The radioactive half-life is $\mathbf{5 2}$ hours.

Fresh human blood was obtained from volunteers 
by venepuncture. Heparin was used as an anticoagulant. Double glass distilled water was used in all of the experiments using calcium.

All reactions were carried out in plastic or polypropylene tubes to minimise the absorptions of $\mathrm{Ca}^{++}$or $\mathrm{Pb}^{++}$which occur with glass and also to avoid the haemolytic effect of glass.

\section{Methods}

\section{DETERMINATION OF RADIOACTIVITY}

Gamma activity counting of ${ }^{203} \mathrm{~Pb}$ samples

${ }^{203} \mathrm{~Pb}$ radioactivity was measured by a LKB-Wallace 1280 ultragamma automatic counter connected to a teletype dynamic-printer. Measurements were made using a $\mathrm{Na}(\mathrm{Tl})$ crystal to detect the activity at 279 $\mathrm{KeV}$, which is specific for ${ }^{203} \mathrm{~Pb}$. Normal precautions and checking of background samples eliminated contamination.

Aqueous solution of ${ }^{45} \mathrm{Ca}$

A LKB 1210 ultrabeta well-type liquid scintillation counter was used to detect the $\beta$-emitting calcium- 45 . The Scintillant used was that of Whyman, ${ }^{8}$ which is $0.6 \%$ PPO in toluene mixed with Triton X-100 $(5: 3, v / v)$.

\section{PROTEIN}

The concentration of protein was measured by the method of Lowry et al. ${ }^{9}$ Bovine serum albumin was used for calibration.

\section{EXTRACTION OF PROTEIN AND LIPID FROM ER Y THROCYTES}

Lipid and protein were extracted from erythrocytes by the method of Mitchell and Hanahan,10 which consists of extracting the ${ }^{203} \mathrm{~Pb}$ - or ${ }^{45} \mathrm{Ca}$-containing samples on two successive occasions with a chloroform/methanol mixture.

Blood samples were incubated with ${ }^{203} \mathrm{~Pb}$ at $37^{\circ} \mathrm{C}$ for two hours in a shaking water bath. Isolation and fractionation into plasma and erythrocyte were achieved using the method described later. A mixture of $1 \mathrm{ml}$ aliquot with $1 \mathrm{ml}$ of chloroform and $1 \mathrm{ml}$ of methanol was then shaken for 30 seconds. After the addition of another millilitre of chloroform, $1 \mathrm{ml}$ of distilled water was added and shaking was continued for 10 minutes. The sample was then centrifuged and separated into three distinct layers; the organic lower phase was the chloroform layer containing the phospholipid while the second aqueous upper phase was the methanolic layer of non-bound free ions. The insoluble protein residue was removed and the procedure was repeated once more. Each fraction was analysed for lead by radioactivity counting.

\section{DISPLACEMENT OF ERYTHROCYTE LEAD BY CALCIUM}

Erythrocytes were incorporated with ${ }^{203} \mathrm{~Pb}$ at a concentration of $2.45 \mu \mathrm{mol} / 1(50 \mu \mathrm{g} / 100 \mathrm{ml})$ for two hours. They were then washed twice with saline buffer and reincubated with fresh plasma containing $\mathrm{CaCl}_{2}$ in concentrations ranging from 20 to 200 $\mu \mathrm{mol} / \mathrm{l}$ at $37^{\circ} \mathrm{C}$ for four hours.

The displacement of ${ }^{203} \mathrm{~Pb}$ was observed by measuring the radioactivity of ${ }^{203} \mathrm{~Pb}$ in the plasma.

\section{DISTRIBUTION OF ${ }^{45} \mathrm{Ca}$ AND ${ }^{203} \mathrm{~Pb}$ IN THE} ERYTHROCYTES

Twenty millilitres of fresh blood were collected and centrifuged at $2500 \mathrm{rpm}$ for 10 minutes, after which the buffy laye. was carefully aspirated. The supernatant and erythrocytes were mixed and incubated for one hour in the presence of $20 \mu \mathrm{Ci}$ of ${ }^{45} \mathrm{Ca}$ or ${ }^{203} \mathrm{~Pb}$. After incubation the cells were spun down at $3000 \mathrm{rpm}$, and the plasma fraction was aspirated. The red cells were washed four times with 10 volumes of cold isotonic saline and were then lysed with five volumes of water. The total volume of the lysate was measured and a one-millilitre fraction was removed for radioactivity estimation. The stroma (ghosts) was separated from the rest of the lysate by centrifugation at $30000 \mathrm{~g}$ for $\mathbf{4 0}$ minutes and then freed from haemoglobin according to the method of Maddy. ${ }^{11}$ The amount of radioactivity in the entire amount of the stroma was measured. All the separations were done at $4^{\circ} \mathrm{C}$.

The radioactivity in whole blood, plasma, lysate, and the stroma was determined by $\beta+\gamma-$ counting, and the percentage of activity in each fraction was also calculated.

PREPARATION OF ERYTHROCYTE MEMBRANES The stepwise osmotic haemolysis method of Dodge et al $^{12}$ was used for human RBC membrane preparation. This method was reported by the authors to cause minimal loss of membrane proteins and maximal loss of haemoglobin. ${ }^{13}$

The use of EDTA in the method, however, creates some problems. Using this reagent more haemoglobin is released from the membrane but some of the loosely bound protein probably accompanied it. In addition, the lead would also be chelated and thus make the results difficult to interpret. Therefore this reagent was not used.

Samples of fresh human blood were used in this study. The blood was preincorporated with ${ }^{203} \mathrm{PbCl}_{2}$ (final concentration $2.45 \mu \mathrm{mol} / \mathrm{l}$ ) for 90 minutes at $37^{\circ} \mathrm{C}$. The plasma and buffy layer were carefully 
removed by aspiration. Particular attention was directed to eliminating the white blood cells as much as possible. For this reason there was considerable loss of red cells.

CHEMICAL MODIFICATION OF ERYTHROCYTE MEMBR A N ES

Chemical reagents were used to identify the principal binding molecule(s) in the membrane. The methods of introducing these group specific agents were as follows.

\section{Reaction with carbodi-imide: modification of carboxyl groups}

The procedure was based on the method of Carraway and Koshland. ${ }^{14}$ Membranes were suspended in $0.5 \mathrm{M} \mathrm{NH}_{4} \mathrm{Cl}$ and carbodi-imide was added to give a final concentration of $0.1 \mathrm{M}$. The final volume was $2 \mathrm{ml}$, containing $10 \mathrm{mg}$ membrane protein. The $\mathrm{pH}$ was adjusted to 4.75 by $\mathrm{HCl}$, and the mixture was incubated at $37^{\circ} \mathrm{C}$ for one hour: $0.1 \mathrm{M} \mathrm{HCl}$ was added through the incubation time to maintain a constant $\mathrm{pH}$ of 4.75 . The reaction was terminated by the addition of $10 \mathrm{ml}$ ice-cold $0.5 \mathrm{mM}$ histidineimidazole buffer ( $\mathrm{pH} \mathrm{7.0)}$, and the membranes were centrifuged at $0-4^{\circ} \mathrm{C}$ for 20 minutes at $6000 \mathrm{~g}$. The membranes were washed twice more with this buffer before lead binding was measured.

To determine the effect of cations released from the membrane, ${ }^{45} \mathrm{Ca}$ or ${ }^{203} \mathrm{~Pb}$-containing membranes were incubated with $0.1 \mathrm{M}$ carbodi-imide $(\mathrm{pH} 7.0)$ at $37^{\circ} \mathrm{C}$ for one hour.

Controls in both experiments contained $0 \cdot 1 \mathrm{M}$ histidine-imidazole buffer ( $\mathrm{pH} 7 \cdot 0$ ). The reaction was terminated, and membranes were washed as described above.

Reaction with PCMB: modification of thiol groups A stock solution of $5 \mathrm{mM}$ p-chloromercuribenzoate (PCMB) was prepared in $10 \mathrm{mM}$ phosphate buffer (pH 7.0) by the method of Riordan and Vallee. ${ }^{15}$ Sufficient of this stock solution was added to $10 \mathrm{mg}$ of membrane protein to give a final concentration of $1 \mathrm{mM}$ PCMB in a final volume of $2 \mathrm{ml}$. Incubation was carried out at $37^{\circ} \mathrm{C}$ for one hour. Controls contained $10 \mathrm{mM}$ of phosphate buffer. Since PCMB solubilised $24 \%$ membrane protein, the released cation was removed by dialysis against $0.5 \mathrm{mM}$ histidine-imidazole buffer ( $\mathrm{pH} 7 \cdot 0$ ) overnight at $0-4^{\circ} \mathrm{C}$.

Reaction with maleic anhydride: modification of amino groups

Reaction of amino groups with maleic anhydride was based on the procedure of Klapper and Klotz. ${ }^{16}$ Solid maleic anhydride was slowly added to $10 \mathrm{mg}$ of membrane protein in $2 \mathrm{ml}$ of histidine-imidazole buffer. The final concentration of maleic anhydride was $0.1 \mathrm{M}$ and the acylation was carried out at $4^{\circ} \mathrm{C}$ for 30 minutes. The $\mathrm{pH}$ was maintained at 7.0 by the addition of $0.2 \mathrm{M} \mathrm{NaOH}$. The control contained $0 \cdot 1 \mathrm{M}$ histidine-imidazole buffer, $\mathrm{pH} 7 \cdot 0$. Unreacted maleic anhydride and free cations were removed by dialysis as previously described for the thiol modification procedure.

FRACTIONATION OF ERYTHROCYTE

MEMBRANE BY GEL CHROMATOGRAPHY

The gel filtration technique used for fractionation of membrane protein was that described by Andrews. ${ }^{17}$ Cross-linked dextran sephadex-G with a water regain of $19 \mathrm{~g} / \mathrm{g}$ of gel and particle size of $120-400$ mesh was used. Filtration was performed in a plexiglass column $(120 \times 3.2 \mathrm{~cm})$.

The column was predetermined and standardised with commercially available proteins of known molecular weight. The protein standards used were: human gammaglobulin, conalbumin, cytochrome-C, myoglobin, and trypsin.

Protein separations were performed with a column equilibrated with $0 \cdot 1 \mathrm{M}$ Tris- $\mathrm{HCl}(\mathrm{pH} \mathrm{8.0)}$ containing $1 \mathrm{M} \mathrm{NaCl}$ and $0.02 \%$ sodium azide as a preservative. The flow rate was maintained at $24 \mathrm{ml} / \mathrm{hr}$ by adjusting the hydrostatic pressure. All experiments were done at room temperature. Erythrocyte membranes labelled with ${ }^{45} \mathrm{Ca}$ or ${ }^{203} \mathrm{~Pb}$ were dissolved in the equilibration buffer to a total volume of about $10 \mathrm{ml}$, and the solution was carefully applied to the top of the column by layering the buffer already present. The column effluent was collected with a LKB Radi-Rac-rotator.

Proteins were estimated spectrophotometrically using a Pye Unicam SP-600 with a $1 \mathrm{~cm}$ light cuvette and transmission at $280 \mathrm{~nm}$.

\section{Results}

EFFECTS OF $\mathrm{CaCl}_{2}$ ON THE RELEASE OF ${ }^{203} \mathrm{~PB}$ FROM ERYTHROCYTES

In control experiments, when leaded erythrocytes were incubated in $0.9 \%$ saline buffer, only $4 \%$ of the total ${ }^{203} \mathrm{~Pb}$ eluted. This ${ }^{203} \mathrm{~Pb}$ found in the supernatant may be due either to a small degree of passive exchange of $\mathrm{Pb}^{++}$with other cations, or to some haemolysis and subsequent loss of haemoglobin during the washing of red cells, whereas for leaded erythrocytes incubated in fresh plasma (without addition of $\mathrm{CaCl}_{2}$ ), about $14 \%$ of the ${ }^{203} \mathrm{~Pb}$ was released. That a higher percentage of ${ }^{203} \mathrm{~Pb}$ appeared in the plasma than in the saline buffer can probably be attributed to an affinity the plasma or its constituents have for ${ }^{203} \mathrm{~Pb}$, so that those lead ions not 


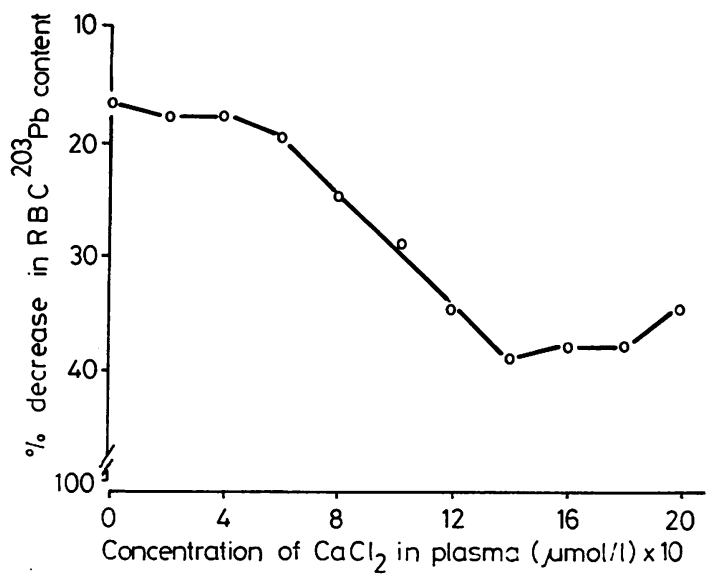

Fig 1 Effects of $\mathrm{CaCl}_{2}$ on release of ${ }^{203} \mathrm{~Pb}$.

firmly bound to the red cells may have moved out of the erythrocytes and bound to the plasma.

Figure 1 shows the displacement of ${ }^{203} \mathrm{~Pb}$ from human erythrocytes after four hours incubation in plasma with various concentrations of calcium chloride (in each case as a mean of two experiments). The increase in lead displacement was not obvious until the added calcium chloride concentration reached $60 \mu \mathrm{mol} / \mathrm{l}$. When the added calcium chloride concentration was above $120 \mu \mathrm{mol} / \mathrm{l}$, however, no further significant effect on the red cells was observed. This probably occurred because the high concentration of calcium chloride caused agglutination of red blood cells.

\section{Distribution OF $\mathrm{Ca}^{++}$AND $\mathrm{Pb}^{++}$IN THE ERYTHROCYTES}

Table 1 shows the percentage distribution of ${ }^{45} \mathrm{Ca}$ and ${ }^{203} \mathrm{~Pb}$ in haemolysate and stromal membranes determined from three experiments each carried out in duplicate. The results showed a significant difference in the binding behaviour; $85 \%$ of ${ }^{203} \mathrm{~Pb}$ had penetrated into the red cells to bind with the cytoplasmic components. On the other hand, only $10.8 \%$ of ${ }^{45} \mathrm{Ca}$ was associated with the cytoplasmic components-that is, the main binding fraction for ${ }^{45} \mathrm{Ca}$ was the stromal membrane. This high percentage

Table 1 Distribution of ${ }^{45} \mathrm{Ca}$ and ${ }^{203} \mathrm{~Pb}$ in the erythrocyte

\begin{tabular}{lll}
\hline Nuclide & \multicolumn{2}{l}{ Percent distribution (Mean \pm SEM) } \\
\cline { 2 - 3 } & Membrane & Cytosol \\
\hline${ }^{45} \mathrm{Ca}$ & $89.2 \pm 9.9$ & $10.8 \pm 1.6$ \\
${ }^{203} \mathrm{~Pb}$ & $14.9 \pm 1.7$ & $85.1 \pm 8.9$ \\
\hline
\end{tabular}

Table 2 Distribution of $\mathrm{Ca}^{++}$and $\mathrm{Pb}^{++}$in the erythrocyte membrane

\begin{tabular}{llll}
\hline Nuclide & \multicolumn{4}{l}{ Fraction (percent recovered) $($ Mean $\pm S E M)$} \\
\cline { 2 - 4 } & Protein & Lipid & Aqueous \\
\hline${ }^{45} \mathrm{Ca}$ & $88.4 \pm 1.76$ & $9.0 \pm 0.95$ & $2.6 \pm 0.65$ \\
${ }^{203} \mathrm{~Pb}$ & $92.3 \pm 1.84$ & $6.7 \pm 1.4$ & $1.3 \pm 0.20$ \\
\hline
\end{tabular}

of calcium found in the erythrocyte membrane confirms the observations reported by Schatzmann and Vincenzi. ${ }^{18}$

\section{Distribution of $\mathrm{Ca}^{++}$AND $\mathrm{Pb}^{++}$AT}

MOLECULAR LEVEL

Table 2 shows the results of ${ }^{45} \mathrm{Ca}$ and ${ }^{203} \mathrm{~Pb}$ distribution in the erythrocyte membranes as determined from three experiments, each carried out in duplicate. The radioactivity recovery was $92 \%$. There is no significant difference in the distribution of these two cations at molecular level. The protein fraction that contained most of both nuclides accounted for $88.4 \%$ of ${ }^{45} \mathrm{Ca}$ and $92 \%$ of ${ }^{203} \mathrm{~Pb}$. About $9.0 \%$ of the ${ }^{45} \mathrm{Ca}$ and $6.7 \%$ of ${ }^{203} \mathrm{~Pb}$ were found in the lipidcontaining phase. Only traces of the labelled materials were recovered in aqueous form, probably released from either protein or lipid molecules during extraction. The lead distribution pattern in the present investigation confirms the low affinity of inorganic lead for phospholipid reported by Beattie et al. ${ }^{19}$

GROUPS BINDING ${ }^{203} \mathrm{~Pb}$ AND ${ }^{45} \mathrm{Ca}$

The effects of chemicals affecting different binding groups on the binding and release of ${ }^{45} \mathrm{Ca}$ and ${ }^{203} \mathrm{~Pb}$ are shown in tables 3 and 4 , which present the results of three experiments, each carried out in duplicate.

The activity of the membrane carboxyl group when treated with 1-cyclohexyl-3-c (morpholinoethyl) carbodi-imide methotoluene-p-sulphonate significantly decreased. The capacity of the membrane to bind both ${ }^{45} \mathrm{Ca}$ and ${ }^{203} \mathrm{~Pb}$ - that is, the change as a percentage of the control is about $68 \%$ both for calcium and for lead. Treatment of nuclidecontaining erythrocyte membrane with this chemical also released considerable amounts of ${ }^{45} \mathrm{Ca}$ and ${ }^{203} \mathrm{~Pb}$, about $52 \%$ in both cases.

On the other hand, blocking the erythrocyte membrane SH groups with PCMB did not appreciably change the binding pattern. The capacity of the membrane to bind ${ }^{45} \mathrm{Ca}$ and ${ }^{203} \mathrm{~Pb}$ was reduced by about $18.4 \%$. When erythrocyte membranes containing ${ }^{45} \mathrm{Ca}$ and ${ }^{203} \mathrm{~Pb}$ were treated with this agent, about $16 \%$ of ${ }^{45} \mathrm{Ca}$ and a similar amount of ${ }^{203} \mathrm{~Pb}$ were released. 
Table 3 Effects of chemicals on membrane ${ }^{45} \mathrm{Ca}$ uptake and release

\begin{tabular}{|c|c|c|c|c|c|c|}
\hline \multirow[t]{3}{*}{ Chemical } & \multicolumn{6}{|c|}{ nmoles of $\mathrm{Ca}^{++}$bound/mg membrane protein $($Mean $\pm S E M)$} \\
\hline & \multicolumn{3}{|c|}{ Treatment before binding } & \multicolumn{3}{|c|}{ Treatment after binding } \\
\hline & Control & Treated & $\%$ change & Control & Treated & $\%$ change \\
\hline $\begin{array}{l}\text { Carbodi-imide } \\
\text { p-chloromercuribenzoate } \\
\text { Maleic anhydride }\end{array}$ & $\begin{array}{l}72 \cdot 3 \pm 4 \cdot 8 \\
141 \cdot 51 \pm 23 \\
152 \cdot 54 \pm 41\end{array}$ & $\begin{array}{l}22 \cdot 78 \pm 2 \cdot 8 \\
115.47 \pm 24 \\
137.76 \pm 29 \cdot 3\end{array}$ & $\begin{array}{r}68 \cdot 5 \\
18 \cdot 4 \\
9 \cdot 7\end{array}$ & $\begin{array}{l}290.56 \pm 45 \\
214.9 \pm 42.4 \\
242 \cdot 3 \pm 70.9\end{array}$ & $\begin{array}{l}137 \cdot 12 \pm 23 \cdot 2 \\
180 \cdot 4 \pm 43 \cdot 5 \\
236 \cdot 2 \pm 69 \cdot 0\end{array}$ & $\begin{array}{r}52 \cdot 8 \\
16 \cdot 1 \\
2 \cdot 5\end{array}$ \\
\hline
\end{tabular}

Table 4 Effects of chemicals on membrane ${ }^{203} \mathrm{~Pb}$ uptake and release

\begin{tabular}{|c|c|c|c|c|c|c|}
\hline \multirow[t]{3}{*}{ Chemical } & \multicolumn{6}{|c|}{ nmoles of $\mathrm{Pb}^{++}$bound/mg membrane protein $($Mean $\pm S E M)$} \\
\hline & \multicolumn{3}{|c|}{ Treatment before binding } & \multicolumn{3}{|c|}{ Treatment after binding } \\
\hline & Control & Treated & $\%$ change & Control & Treated & $\%$ change \\
\hline $\begin{array}{l}\text { Carbodi-imide } \\
\text { p-chloromercuribenzoate } \\
\text { Maleic anhydride }\end{array}$ & $\begin{array}{r}42 \cdot 3 \pm 3 \cdot 2 \\
91 \cdot 3 \pm 4 \cdot 7 \\
105 \cdot 2 \pm 6 \cdot 7\end{array}$ & $\begin{array}{l}13.4 \pm 0.8 \\
74.5 \pm 4.6 \\
98.7 \pm 6.3\end{array}$ & $\begin{array}{r}68 \cdot 3 \\
18 \cdot 4 \\
6 \cdot 2\end{array}$ & $\begin{array}{l}181 \cdot 6 \pm 14.7 \\
153.5 \pm 11 \cdot 7 \\
170.3 \pm 9.4\end{array}$ & $\begin{array}{r}85 \cdot 7 \pm 6 \cdot 3 \\
128 \cdot 9 \pm 10 \cdot 8 \\
166 \cdot 3 \pm 11 \cdot 3\end{array}$ & $\begin{array}{r}52 \cdot 8 \\
16 \cdot 0 \\
2 \cdot 3\end{array}$ \\
\hline
\end{tabular}

Inhibition of the membrane amino groups of the erythrocyte membrane proteins with maleic anhydride showed that the capacity to bind both ${ }^{45} \mathrm{Ca}$ and ${ }^{203} \mathrm{~Pb}$ was only slightly reduced.

These results suggest that the binding groups in the red cell membrane for calcium and lead are similarthat is, the carboxyl groups are primarily responsible for the binding, other groups playing only a minor part.

\section{DISTRIBUTION OF CALCIUM AND LEAD IN} THE ERYTHROCYTE MEMBRANES

Lead and calcium have been shown to be associated with erythrocyte membrane protein (table 2). Attempts were made to define more closely the principal binding groups of these two cations in the stromal membrane by gel chromatography.

Erythrocytes that had been incorporated with either ${ }^{45} \mathrm{Ca}$ or ${ }^{203} \mathrm{~Pb}$ were isolated from the plasma, and the stromal membranes were prepared according to the method of Dodge et al. .12 $^{2}$ The membrane (ghosts) pellet was then washed three times to remove the cations loosely associated with the membrane, leaving the nuclides that were firmly bound. The labelled stromal membranes were then dissolved in Triton-X-100, and the polypeptides were denatured and separated in Sephadex G-200.

Figure 2 is the chromatogram of the membranes before removal of lipids. Most of the recovered ${ }^{45} \mathrm{Ca}$ was associated with fraction $43-45$, corresponding to a high molecular weight component of molecular weight 130000 to 230000 .

Evidence that ${ }^{203} \mathrm{~Pb}$ is probably bound to the same molecular groups as ${ }^{45} \mathrm{Ca}$ comes from the finding that ${ }^{203} \mathrm{~Pb}$ also appeared in the fraction of similar molecular weight (fig 3 ).

\section{Discussion}

In this investigation a high proportion ( $85 \%$ ) of lead in the erythrocyte was associated with the intracellular constituents, and only a relatively small amount (less than $15 \%$ ) was present in the stromal membrane. This distribution pattern may explain the contradictory published reports with regard to the site of lead binding in the erythrocytes. Earlier workers ${ }^{20-23}$ reported that lead was associated with the erythrocyte membrane, whereas Barltrop and Smith ${ }^{24} 25$ reported that lead was firmly bound to the cytoplasmic constituents of the erythrocyte. These groups of investigators apparently did not differentiate the two fractions.

The finding that $90 \%{ }^{45} \mathrm{Ca}$ was attached to the erythrocyte membrane is in agreement with Forster and Manery, ${ }^{26}$ who showed that the binding of $\mathrm{Ca}^{++}$ within the erythrocyte was of minor importance. The limited uptake of ${ }^{203} \mathrm{~Pb}$ by the erythrocyte membrane is in accordance with the finding of Bruenger et al, ${ }^{27}$ who used ${ }^{210} \mathrm{~Pb}$ as a tracer.

The stepwise osmotic haemolysis ${ }^{12}$ technique used throughout these experiments was chosen because three washes of ghosts (membrane) pellet would be expected to remove the cations loosely associated with the membrane and leave only the cations that were firmly bound. Extraction experiments by chloroform/methanol show that both calcium and lead cations were firmly bound, as about $90 \%$ of the total ghosts $\mathrm{Ca}^{++}$and $\mathrm{Pb}^{++}$were recovered bound firmly to membrane proteins, whereas less than $3 \%$ was present in the aqueous phase (table 2).

It is difficult, however, to draw an overall conclusion from these findings, as the exact composition 


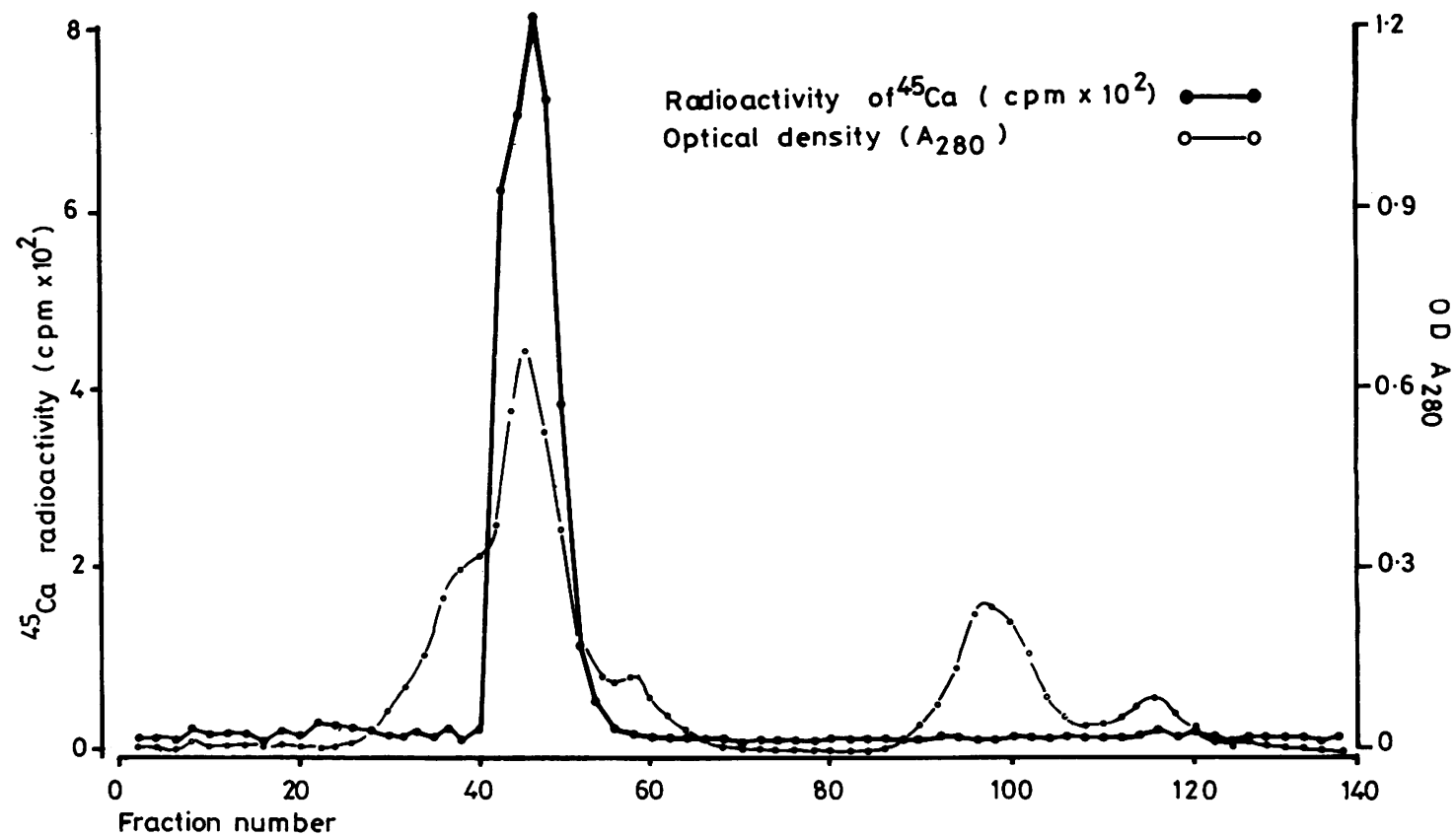

Fig 2 G-200 Sephadex chromatography of ${ }^{45}$ Ca-labelled erythrocyte membrane.

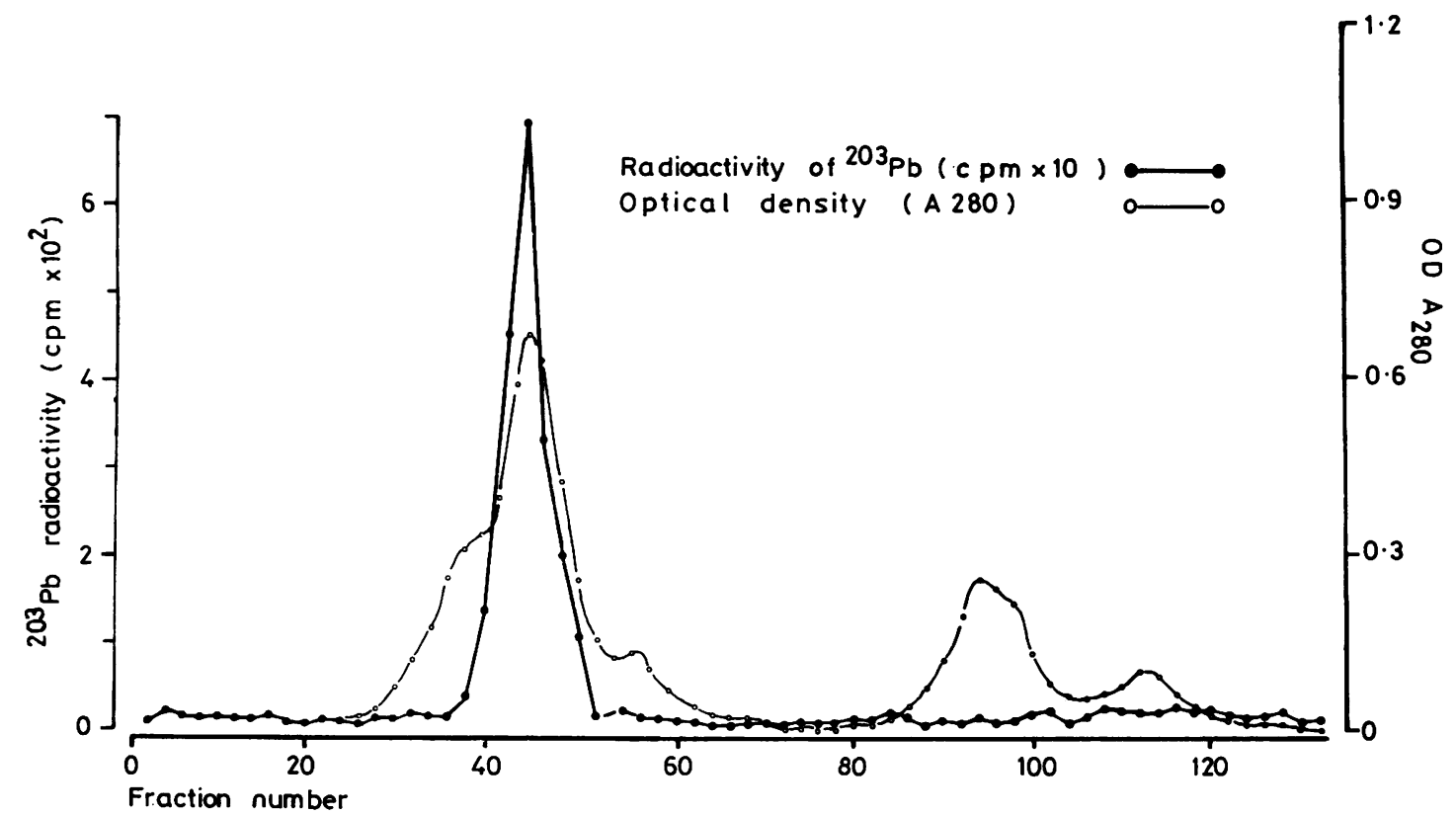

Fig 3 G-200 Sephadex chromatography of ${ }^{203}$ Pb-labelled erythrocyte membrane. 
of the membrane in the isolated state may differ from that in the intact erythrocyte. In the process of membrane isolation certain proteins or lipids may be washed off. If the membrane composition does differ in the isolated state then possibly some of the binding molecules may have been missing in the present investigation.

It is also possible that in washing the membranes the protein may experience conformational changes. If such changes do occur in the transition from the native to the isolated state then the calcium and leadbinding properties could also alter.

Although the distribution patterns of ${ }^{45} \mathrm{Ca}$ and ${ }^{203} \mathrm{~Pb}$ in the erythrocytes were different (table 1), lead appeared to have a high affinity for intracellular constituents of RBC and less for stromal membrane, whereas calcium was found mainly attached to the RBC membrane $(89 \cdot 2 \%)$. But detailed examination of lead binding sites in the stromal membrane indicated that both cations have a mutual binding site on the erythrocyte membrane, presumably of identical molecular group-that is, carboxyl group (figs 2 and 3 and table 2).

The results of exposing leaded erythrocytes to calcium in our in-vitro system, indicate that posttreatment with calcium reduces the lead content of the red cells. This observation suggests that calcium may influence the transportation of lead from cell to plasma, and that the concentration of calcium in plasma or extracellular fluid may influence the activity of lead. These in-vitro observations confirm the in-vivo experiments noted by Rosen, ${ }^{28}$ who showed that in lead-intoxicated rats challenging with calcium above a specific concentration threshold produces a rapid decrease in lead content of red cells.

The finding that lead interacts with the carboxyl group is noteworthy because it may explain the mechanism by which lead inhibits the activity of $\mathrm{Na}^{+} / \mathrm{K}^{+}$-ATPase, ${ }^{29} 30$ as membrane carboxyl groups are known to be involved in the formation of the intermediate $\mathrm{Na}^{+} / \mathrm{K}^{+}$-ATPase. ${ }^{31}$ If lead combines with carboxyl groups at the active site of $\mathrm{Na}^{+} / \mathrm{K}^{+}$-ATPase the phosphorylation activity of the enzyme would be prevented.

The evidence that calcium and lead interact on the same site(s) on the erythrocyte can be summarised as follows.

(1) More than $90 \%$ of the ${ }^{203} \mathrm{~Pb}$ in the erythrocyte membrane was associated with membrane protein (table 2). Extraction of $\mathrm{Ca}^{++}$has shown that a very high proportion $(88 \%)$ of this cation in red cells membrane was also protein bound.

(2) Sephadex G-200 chromatography of ${ }^{45} \mathrm{Ca}-$ and ${ }^{203} \mathrm{~Pb}$-labelled erythrocyte membranes indicated that the calcium binding fraction is also the lead binding fraction (figs 2 and 3), which is of molecular weight
130000 to 230000 . Use of group specific agents to identify the binding molecule(s) suggested that carboxyl groups are primarily responsible for the binding of both lead and calcium in the erythrocyte membrane.

(3) Calcium ions in the plasma were shown to be capable of replacing the ${ }^{203} \mathrm{~Pb}$ on the erythrocytes.

We thank the Medical Research Council Cyclotron Unit, Hammersmith Hospital, and the Radiation Protection Service, University of Manchester, for supplying the radioisotopes ${ }^{203} \mathrm{~Pb}$ and ${ }^{45} \mathrm{Ca}$. We are also very indebted to $\mathrm{Mr} \mathbf{C ~ J}$ Whitaker not only for statistical help but also for his help in the preparation of this paper.

This work formed part of a thesis submitted for the degree of $\mathrm{Ph} \mathrm{D}$ to the University of Manchester by $\mathrm{C}$ N Ong.

\section{References}

${ }^{1}$ Goyer RA, Rhyne BC. Pathological effects of lead. Int Rev Exp Pathol 1973;12:1-67.

2 Meredith PA, Moore MR, Goldberg A. Depression of oral lead absorption by calcium salts. Scott Med J 1975;20:41.

${ }^{3}$ Sorell M, Rosen JF, Reginsky M. Interaction of lead, calcium, vitamin $D$ and nutrition in lead-burdened children. Pediatr Res $1976 ; 10: 415$.

${ }^{4}$ Rosen JF, Trinidad EE. Significance of plasma-lead levels in normal and lead-intoxicated children. Environ Health Perspect 1974;7:139-45.

${ }^{5}$ Kostial K, Vouk VB. Lead ions and synaptic transmission in the superior cervical ganglion of the cat. $\mathrm{Br} J$ Pharmacol 1957;12:219-24.

${ }^{6}$ Kober TE, Copper GP. Lead competitively inhibits calcium-dependent synaptic transmission in the bullfrog sympathetic ganglion. Nature 1976;262:704.

7 Manalis RS, Copper GP. Presynaptic and postsynaptic effects of lead on frog neuromuscular junction. Nature 1973;243:354.

${ }^{8}$ Whyman AE. Measurement of plasma and urine with a toluene/triton X-100 Scintillant. Int J Appl Radiat Isot $1970 ; 21: 81-5$.

${ }^{9}$ Lowry OH, Rosbrough NJ, Farr AC, Randall RJ. Protein measurement with the Folin-Phenol reagent. J Biol Chem $1951 ; 193: 265-70$.

${ }^{10}$ Mitchell CD, Hanahan DJ. Solubilisation of certain proteins from the human erythrocyte stroma. Biochemistry 1966;5:51-9.

${ }^{11}$ Maddy AH. Red blood cell membrane proteins. Semin Haematol 1970;7:175-92.

12 Dodge JT, Mitchell C, Hanahan DJ. The preparation and chemical characteristics of haemoglobin free 'ghosts' of human erythrocytes. Arch Biochem Biophys 1963;100: 19-26.

${ }^{13}$ Hanahan DJ, Dodge JT. Is lipid lost during preparation of erythrocyte membranes? Biochem Biophys Acta 1974; 363:283-8.

14 Carraway K, Koshland D. Carbodi-imide modification of proteins. Methods Enzymol 1972;25:616.

15 Riordan JF, Vallee BL. Reaction with N-ethylmaleimide and p-mercuribenzoate. Methods Enzymol 1967;11:541.

${ }^{16}$ Klapper M, Klotz I. Acylation with dicarboxylic acid anhydrides. Methods Enzymol 1972;25:531-2.

${ }_{17}$ Andrews P. Estimation of the molecular weights of 
proteins by Sephadex gel-filtration. Biochem J 1964;91: 222-31.

${ }^{18}$ Schatzmann HJ, Vincenzi FF. Calcium ion movements across the membrane of human red cells. J Physiol (Lond) 1969;201:369-95.

${ }^{19}$ Beattie AD, Moore MR, Goldberg A. Tetraethyl-lead poisoning. Lancet 1972;2:12-5.

${ }^{20}$ Aub JC, Reznikoff $P$. The effects of lead on red blood cells. $J$ Exp Med 1924;40:189-93.

${ }^{21}$ Reddi KK. Isolation of thorium-B (lead) binding substance from erythrocyte of rabbit blood. Nature 1953; 172:202.

${ }^{22}$ Clarkson TW, Kench JE. Uptake of lead by human erythrocyte in vitro. Biochem $J$ 1958;69:432-8.

${ }^{23}$ White JM. Lead and the red cell. Br J Haematol 1975;30: 991-8.

${ }^{24}$ Barltrop D, Smith A. Interaction of lead with erythrocytes. Experientia 1971;27:92-4.
${ }^{25}$ Barltrop D, Smith A. Lead binding to human haemoglobin. Experientia 1972;28:76-7.

${ }^{26}$ Forster J, Manery JF. Calcium binding by human erythrocyte membrane. Biochem J 1971;124:563-9.

27 Bruenger FW, Stevens W, Stover BJ. The association of $\mathrm{Pb}-210$ with constituents of erythrocytes. Health Phys $1973 ; 25: 37-42$.

${ }^{28}$ Rosen JF. Action of calcitonin and parathyroid hormone in lead-intoxicated rats. Pediatr Res 1972;6:401-4.

${ }^{28}$ Hasan J, Hernberg S. Interaction of inorganic lead with human red cells. Work Environ Health 1966;2:26-47.

${ }^{30}$ Secchi GC, Alessio L, Cambiaghi G. $\mathrm{Na}^{+} / \mathrm{K}^{+}$-ATPase activity of erythrocyte membranes. Arch Environ Health $1973 ; 27: 399-401$.

${ }^{31}$ Duffy M, Schwarz V. Molecular groups responsible for the binding of calcium ions in the erythrocyte membrane Biochem Soc Trans 1974;2:403-4.

\section{The November 1979 issue}

\section{THE NOVEMBER 1979 ISSUE CONTAINS THE FOLLOWING PAPERS}

\section{The Pearson Report J M COLLINSON}

A cohort study of mortality and cancer incidence in ethylene oxide production workers C HOGSTEDT, O ROHLÉN, B S BERNDTSSON, O AXELSON, AND L EHRENBERG

UK Naval Dockyards Asbestosis Study: survey of the sample population aged 50-59 years C E ROSSITER AND P G HARRIES

Oral and pharyngeal cancer in the North-west and West Yorkshire regions of England, and occupation C J WHITAKer, E MOSS, W $R$ LEE, AND STELLA CUNLIFFE

Bacterial contamination of cotton as an indicator of respiratory effects among card room workers R RYLANDER, H R IMBUS, AND M W SUH

Mill effect and dose-response relationships in byssinosis $R$ N JONES, J E DIEM, H GLINDMEYER, $V$ DHARMARAJAN, $Y$ Y HAMMAD, J CARR, AND H WEILL
Occupational lead poisoning in the United States: clinical and biochemical findings related to blood lead levels $E$ L BAKER, JR, $P$ J LANDRIGAN, A G Barbour, D H COX, D S FOLlaND, R N Ligo, AND J THROCKMORTON

5-aminolevulinate dehydratase activity in blood of rabbits given tin or lead MOMOKO CHIBA AND MASAKAZU KIKUCHI

The distribution and metabolism of nickel carbonyl in mice AGNETA OSKARSSON AND H TJÄLVE

Hand grip forces during chain saw operation and vibration white finger in lumberjacks M FÄRKKILÄ, I PYYKKÖ, O KORHONEN, AND JUKKA STARCK

Book reviews

Notices

Information section

Index

Copies are still available and may be obtained from the PUBLISHING MANAGER, BRITISH MEDICAL ASSOCIATION, TAVISTOCK SQUARE, LONDON WClH 9JR, price $£ 4.25$ (USA \$9.20), including postage 